\title{
Ekologi Bermedia Masyarakat dalam Praktik Worship From Home
}

\author{
Dessy Dwi Lestari ${ }^{1}$, Belda Eldrit Janitra ${ }^{2}$ \\ 1, 2 Universitas Islam Negeri Sunan Ampel Surabaya \\ 1dessy11april@gmail.com_beldaeldritjanitra@gmail.com
}

\begin{abstract}
In this digital society era, media is something which cannot be separated from human daily life. Especially when the media developed rapidly after the presence of new media in the form of the internet and its various applications and social media. The public feels that it is greatly facilitated by the presence of the media, in fact the term world in your grasp is not just nonsense. Every second the public is able to find out the update news from around the world just by typing a few keywords. Including the news of the COVID-19 pandemic that spreads all over the world. Until the Indonesian government always disseminates policies and the latest news about this virus through various media. People are encouraged to remain calm and stay at home to prevent the transmission of this disease. One of the government policies conveyed by the Indonesian Ministry of Religion is the protocol for worship at home or better known as Worship From Home. This issue is interesting to be studied more deeply through qualitative research methods to obtain as much information as possible through interviews and observations. The results obtained show that there are some people who accept it willingly to practice worship from home, but there are also layers of society that are still lagging behind, because it is still difficult to use the media to practice worship in congregation that is usually done face to face.At this time, the ecology of media is clearly visible. This is where we can see that the media can unite to influence all aspects of people's lives and unite the whole world including in terms of organizing religious experiences.
\end{abstract}

Keywords: Media Ecology, Society, Worship, Social Media

\begin{abstract}
Abstrak
Di era masyarakat digital saat ini, media merupakan hal yang tidak bisa dipisahkan dari manusia. Media terus berkembang pesat mulai dari media konvensional hingga saat ini merambah ke media baru (new media). Media baru yang kita kenal saat ini meliputi internet dan berbagai turunannya berupa aplikasi dan media sosial. Kehadiran media baru, mempermudah kegiatan manusia. Bahkan, seluruh kebutuhan informasi dapat dipenuhi oleh media baru ini. Sebagaimana ketika pandemi COVID-19, media memiliki peranan penting dalam memberikan informasi terbaru perkembangan penularan penyakit yang disebabkan oleh virus Corona ini. Media juga menjadi tempat masyarakat dapat mengetahui dengan cepat himbauan dari pemerintah. Salah satu kebijakan pemerintah yang disampaikan oleh Kementerian Agama Indonesia adalah protokol untuk beribadah di rumah atau yang lebih dikenal dengan Worship From Home. Pada saat ini, ekologi media terlihat jelas. Maka tujuan penelitian ini adalah melihat bahwa media dapat mempengaruhi semua aspek kehidupan masyarakat dan menyatukan seluruh dunia termasuk dalam hal mengatur pengalaman keagamaan. Persoalan semacam ini menarik untuk dikaji lebih dalam melalui metode penelitian kualitatif dengan harapan bisa memperoleh informasi sebanyak-banyaknya melalui wawancara dan observasi. Hasil penelitian yang diperoleh menunjukkan bahwa ada sebagian masyarakat yang menerima dengan senang hati untuk melakukan praktik ibadah dari rumah, tetapi ada juga lapisan masyarakat yang masih
\end{abstract}

Jurnal Kopis: Kajian Penelitian dan Pemikiran Komunikasi Penyiaran Islam

Volume 03, Issue 1, Agustus 2020 
tertinggal, sebab masih sulit memanfaatkan media untuk praktik ibadah berjamaah yang biasa dilakukan dengan tatap muka. Pada saat seperti inilah, ekologi bermedia masyarakat terlihat jelas. Di sinilah kita dapat melihat bahwa media dapat mempengaruhi seluruh aspek kehidupan masyarakat dan mempersatukan seluruh dunia dan tentunya dengan berbagai macam pola pikir yang berbeda-beda dan harus disama ratakan demi kepentingan bersama dalam hal kebaikan.

Kata kunci: Ekologi Media, Masyarakat, Ibadah, Media Sosial

\section{Pendahuluan}

Media bukanlah sesuatu yang asing lagi diera ini, dengan berbagai kemajuan teknologi informasi dan komunikasi, media menjadi sahabat dekat bagi manusia. Segala macam informasi mulai dari kabar keluarga hingga berita mancanegara dapat begitu cepat diterima oleh masyarakat. Tidak ketinggalan dengan berita mengenai penyebaran COVID-19 (Corona Virus Disease-2019) yang awalnya dari kota Wuhan, Cina sedang menjadi topik perbincangan utama di seluruh lapisan masyarakat. Penularan virus Corona menjadi ancaman bagi seluruh masyarakat dunia. Terlebih ketika awal Maret ditemukan dua kasus pasien positif COVID19 pertama di Indonesia yang setiap harinya bertambah. Akibatnya, presiden Joko Widodo dan jajaran staf pemerintahan menghimbau masyarakat untuk mematuhi protokol kesehatan yang telah ditetapkan oleh pemerintah salah satunya berkegiatan di rumah saja. Mulai dari meniadakan kegiatan belajar mengajar secara tatap muka, hingga memerintahkan setiap pegawai swasta untuk berkerja dari rumah masing-masing. Pergeseran komunikasi langsung secara diadik maupun kelompok menjadi komunikasi secara virtual melalui new media via aplikasi teleconference pun tidak terelakkan. Siswa diminta untuk melakukan pembelajaran online yang dibimbing oleh guru melalui aplikasi Google Classroom, Ruang Guru, dan lain sebagainya. Para pekerja melakukan koordinasi kerja dan rapat melalui Google Meet, Zoom, dan aplikasi sejenisnya. Hingga kemudian pemerintah memberikan sosialisasi dan protokol pencegahan COVID-19 melalui berbagai media termasuk akun sosial media resmi milik pemerintah guna menghindari kondisi yang dapat meningkatkan penularan virus ini.

Tidak hanya itu, Kementrian Agama RI juga mengeluarkan himbauan mengenai beribadah di rumah saja atau yang kemudian dikenal dengan istilah Worship From Home. Hal ini dilakukan sebagai upaya pencegahan penularan COVID-19. Berbagai Direktorat Jenderal Bimbingan Masyarakat yang dinaungi oleh Kementrian Agama melakukan himbauan masing-masing di akun website dan akun sosial media. Termasuk perkumpulan peribadahan secara berjamaah seperti sholat Jumat bagi umat Islam, ibadah mingguan, pemberkatan di Gereja bagi umat Kristen, hingga rangkaian Pujabakti dan meditasi detikdetik Waisak bagi umat Buddha yang akan dilaksanakan pada bulan Mei 2020 mendatang dihimbau untuk dilakukan secara online agar masyarakat tidak berkerumun dalam masa yang banyak dan untuk menghindari kontak langsung antar sesama jamaah.

Penjelasan di atas merupakan bentuk solusi pemerintah dalam usaha memutus tali penyebaran virus COVID-19 dengan memanfaatkan berbagai macam bentuk media. Fenomena ini jika dikaitkan dengan media, teori yang cocok digunakan dalam mengkaji fenomena tersebut adalah teori ekologi media. Teori ini menekankan bahwa setiap manusia tidak dapat menghindar dari pengaruh media dalam kehidupan, termasuk dalam hal 
peribadatan. Melalui kebijakan yang ditetapkan oleh pemerintah membuat seluruh lapisan masyarakat membuat solusi bagaimana seluruh aktivitas manusia tetap bisa dilakukan.

\section{Metode}

Metode penelitian yang dilakukan dalam penelitian ini adalah metode penelitian kualitatif yang menggambarkan tentang proses penelitian, model penelitian apa yang digunakan, hingga mengkaitkannya dengan teori untuk mengupas permasalahan yang ada dalam penelitian ini. Metode adalah prosedur yang akan digunakan untuk mendekati permasalahan dan menjari jawaban. Dengan kata lain, metodologi merupakan suatu pendekatan umum untuk mengkaji topik penelitian. Metode kualitatif yang digunakan dalam penelitian ini diharapkan dapat mengetahui lebih dalam terhadap fokus permasalahan, sebab peneliti melibatkan diri, mengamati, dan mengasosiasikan pengalaman pribadinya.

Berdasarkan latar belakang permasalahan, maka studi dalam penelitian ini mengambil pendekatan fenomenologi. Menurut Alase (2017), fenomenologi merupakan sebuah metodologi kualitatif yang memperbolehkan peneliti untuk menerapkan dan mengaplikasikan kemampuan subjektivitas dan interpersonalnya dalam proses penelitian eksploratori. Penelitian dengan metode kualitatif dengan pendekatan fenomenologi sangat relevan digunakan dalam meneliti fenomena ibadah dari rumah atau worship from home yang terjadi ketika pandemic COVID-19 saat ini.

Alfred Schutz adalah orang pertama yang menerapkan fenomenologi dalam penelitian ilmu sosial. Schutz mengawali pemikirannya dengan mengatakan bahwa objek penelitian ilmu sosial pada dasarnya berhubungan dengan interpretasi terhadap realitas ${ }^{1}$. Jadi peneliti harus membuat interpretasi terhadap realitas yang diamati. Orang-orang saling terikat satu sama lain ketika membuat interpretasi ini. Menurut Lofland, sumber data utama dalam penelitian kualitatif adalah kata-kata, dan tindakan, selebihnya adalah data.

Teori yang digunakan dalam penelitian ini adalah teori ekologi media. Teori ini menekankan bahwa setiap manusia tidak dapat menghindari pengaruh media dalam kehidupan, termasuk dalam hal peribadatan. McLuhan mengungkapkan bahwa dalam teori ini, media membantu kita untuk mengubah persepsi dan menata kehidupan kita. ${ }^{2}$ Termasuk ketika pandemi COVID-19 barangkali kemarin masyarakat menganggap bahwa penularan virus tersebut hanya terjadi di Wuhan, Cina. Tetapi dengan adanya media, masyarakat jadi tahu bahwa virus tersebut telah menyebar ke seluruh penjuru dunia termasuk Indonesia. Asumsi terakhir dari teori ekologi media adalah media mempersatukan seluruh dunia. McLuhan menggunakan istilah komunitas global. Ini artinya media mampu mengatur masyarakat, secara sosial, ekonomi, politik, dan budaya bahkan pada fenomena ini dalam hal keagamaan. Media elektronik dan new media khususnya memiliki kemampuan untuk menjembatani proses sosial keagamaan masyarakat yang belum pernah bersinggungan dengan koneksi media.

Dalam melakukan penelitian ini, peneliti mengumpulkan data secara kolektif baik secara dari berbagai sumber referensi hingga data online resmi yang dikeluarkan oleh Kementrian Agama RI melalui berbagai website dan akun sosial media. Selanjutnya, proses analisis data dimulai dengan memproses seluruh data yang dikumpulkan dari berbagai sumber, yaitu

${ }^{1}$ Engkus Kuswarno. Fenomenologi: Metode Penelitian Komunikasi: Konsepsi, Pedoman, dan Contoh Penelitian. (Bandung:Widya Padjajaran, 2009), hal.38.

${ }^{2}$ Richard West \& Lynn H. Turner. Pengantar Teori Komunikasi: Analisis dan Aplikasi (Alih Bahasa: Introducing Communication Theory: Analysis and Application). (Jakarta: Salemba Humanika, 2018) hal.183.

Jurnal Kopis: Kajian Penelitian dan Pemikiran Komunikasi Penyiaran Islam

Volume 03, Issue 1, Agustus 2020 
dokumen, wawancara, observasi, dan alat-alat fisik. Setelah data terkumpul proses selanjutnya adalah pengolahan data. Kegiatan pengolahan data umumnya terdiri dari analisis data dan penafsiran data. Dalam penelitian ini hanya akan dilakukan penafsiran data. Setelah dilakukan analisis data dan penafsiran data, selanjutnya adalah langkah untuk memeriksa keabsahan data. Pemeriksaan terhadap keabsahan data pada dasarnya selain digunakan untuk menyanggah balik apa yang dituduhkan kepada penelitian kualitatif yang mengatakan tidak ilmiah, juga merupakan sebagian unsur yang tidak terpisahkan dari tubuh pengetahuan penelitian kualitatif.

\section{Hasil dan Pembahasan}

Secara umum, penelitian ini masuk dalam displin penelitian komunikasi dengan subjek penelitian para pemeluk agama di Indonesia yang mengetahui protokol himbauan peribadatan dan melakukan ibadah di rumah melalui media baik elektronik maupun sosial media. Peneliti mengumpulkan data yang bersumber dari website dan akun resmi Kementrian Agama RI dan direktorat jenderal bimbingan masyarakat beragama, baik agama Islam, Kristen, Katolik, Hindu, Buddha, dan Konghucu.

Meluasnya penularan COVID-19 yang setiap hari semakin bertambah penderitanya, membuat pemerintah mengeluarkan kebijakan melalui berbagai media baik elektronik maupun sosial media. Tercatat per-tanggal 3 April 2020 pukul.16.00 terdapat 1.986 terkonfirmasi kasus positif Corona di Indonesia. Untuk itu awal bulan Maret 2020 pemerintah telah mengeluarkan kebijakan social distancing yakni, dengan menjaga jarak dari kerumunan massa. Hal ini diterapkan dengan langkah meniadakan kegiatan belajar mengajar secara langsung, kegiatan bekerja secara tatap muka, kegiatan massa, dan peribadatan secara berjamaah. Semua kegiatan yang dilakukan secara beramai-ramai dilakukan melalui media elektronik maupun new media dengan menggunakan aplikasi seperti Google Meet, Google Classroom, Ruang Guru, Zoom, Skype dan aplikasi lain sejenisnya.

Dalam keadaan genting seperti ketika pandemi saat ini, Kementrian Agama RI tetap berfungsi sebagai lembaga yang mengatur pembangunan bidang kehidupan keagamaan, oleh karena itu sudah seharusnya lembaga ini mengeluarkan protokol peribadatan di masa pandemi global seperti sekarang. Melalui Majelis Ulama Indonesia (MUI), Kementrian Agama RI juga menghimbau agar umat muslim meniadakan kegiatan ibadah sholat Jumat berjamaah di masjid dan diganti dengan sholat Dzuhur di rumah. Sesuai dengan fatwa MUI pada 17 Maret 2020 yang berbunyi, "Karena hal itu merupakan bagian dari menjaga tujuan pokok beragama (al-Dharuriyat al-Khams)," Fatwa Nomor 14 Tahun 2020 itu. Pemerintah menjadikan fatwa ini sebagai pedoman dalam upaya penanggulangan COVID-19 terkait dengan masalah keagamaan dan umat Islam wajib mentaatinya. Fatwa ini ditandatangani langsung oleh Ketua Komisi Fatwa, H. Hasanuddin dan Sekretaris, HM. Asrorun Ni'am Sholeh.

Umat muslim yang saat ini banyak berkegiatan di rumah, dapat mengetahui fatwa itu melalui media elektronik seperti televisi dan radio maupun melalui sosial media seperti Twitter, Instagram, Facebook, atau portal berita online. Di sinilah ekologi media dalam masyarakat terlaksana. Ketika dahulu, masyarakat hanya memperoleh informasi melalui 
media cetak yang ketika memperolehnya harus membeli keluar rumah, saat ini masyarakat dapat mengetahui informasi terbaru termasuk mengenai fatwa beribadah hanya dari rumah melalui media dalam genggamannya.

Tidak hanya itu, penerapan Worship From Home atau beribadah dari rumah juga dilakukan dalam bentuk kajian online. Beberapa ustadz seperti ustadz Abdul Shomad, ustadz Yazid Abdul Qadir Jawas, Ustadz Abu Yahya Badrussalam dan masih banyak lagi ustadzustadz lainnya yang menggunakan media online berupa Live Radio Streaming, siapapun dan dimanapun umat muslim berada dapat menyimak materi kajian tersebut. Tentunya dengan berbagai macam topik yang menarik disajikan. Sehingga pendengar tetap setia dan intens mengikuti kajian-kajian berikutnya.Terkait Respon para jamaah pengajian terutama ibu-ibu, demi memutus penyebaran virus covid-19 mereka setuju adanya kajian online ini, namun ada sedikit keresahan bagi para ibu-ibu yang tidak memiliki handphone dengan paket data yang kuat sebab, kajian ini menggunakan live streaming yang cenderung cepat menghabiskan paket data. Meski begitu, banyak kajian secara gratis yang masih bisa diikuti melalui media televisi dan media radio.

Tidak hanya umat Islam, dalam memutus penyebaran virus COVID-19 bimbingan masyarakat Kristen dan Katolik juga melakukan himbauan untuk umatnya. Banyak gerejagereja di Indonesia yang membuat cara bagaimana ibadah tersebut bisa tetap dilakukan. Seperti gereja di kota Bandung yang menjadi salah satu titik dari beberapa daerah yang terpapar penyebaran virus Corona atau COVID-19 di Jawa Barat. Para pimpinan gerejagereja tak terkecuali ikut mengambil sikap untuk memutus rantai penularan virus yang berasal dari Wuhan, China tersebut dengan cara membuat kesepakatan dengan mengalihkan ibadah Sabtu dan Minggu dari gedung-gedung gereja ke rumah jemaat masing-masing. Aturan itu berlaku untuk ibadah pada 21-22 dan 28-29 Maret 2020.Sikap tersebut diambil berdasarkan rapat pemimpin gereja-gereja di Kota Bandung yang berasal dari 26 sinode gereja dan puluhan lembaga keumatan Kristen serta gereja yang mengikuti pertemuan tersebut melalui teleconference pada Kamis (19/3/2020) lalu.

Terkait bagaimana responnya tentu bisa dirasakan sendiri oleh beberapa pemimpin gereja yang salah satunya adalah Pendeta Christian Tirtha, beliau mengaku merasa canggung dan tidak terbiasa. Gereja biasanya penuh dengan orang-orang kini sepi tidak ada siapapun, bahkan yang beliau rasa hanya seperti meihat wajahnya sendiri dalam laptop. Kehadiran fisik di ruang ibadah sudah menjadi faktor yang penting bagi umat Kristen, meski secara teologis gereja tidak identik dengan bangunan gedung atau ruang ibadah. "Gereja lebih identik dengan orang Kristen yang berkumpul untuk bersama-sama belajar menjadi semakin seperti Kristus."

Kemudian dalam segi pelaksanannya ibadahnya tentu tidak ada bedanya, bahkan salah satu jemaat ICC yang mengikuti kebaktian online merasa cukup puas dengan metode ibadah ini meski tidak ideal. Mungkin yang mengganggu adalah kalau tiba-tiba koneksi tersendat. Sebagai jemaat menurutnya memang ada bagusnya ibadah online karena bisa mencegah penularan virusnya, dan jemaat menghargai gereja-gereja yang memberi opsi ini." karena Ia berharap keputusan ibadah online juga bisa membantu upaya social distancing yang diterapkan Pemerintah Australia, untuk memutus tali penyebaran COVID-19 ini.

Hasil penelitian ini terkait dengan ekologi media masyarakat dalam praktik worship from bome adalah dalam teori ekologi media McLuhan menjelaskan bagaimana pembentukan

Jurnal Kopis: Kajian Penelitian dan Pemikiran Komunikasi Penyiaran Islam

Volume 03, Issue 1, Agustus 2020 
media. Asumsi pertama dalam teori ini adalah media mempengaruhi hampir seluruh aspek dalam tindak tanduk masyarakat. Terkait fenomena dalam penelitian ini, kita bisa temukan bahwa dampak dari pandemi COVID-19 yang mengharuskan masyarakat berkegiatan di rumah saja, media menjadi sarana hiburan, sarana untuk belajar, dan sarana untuk bekerja yang kemudian mempengaruhi segala perilaku masyarakat. Terutama kegiatan belajar, bekerja, dan beribadah yang tadinya dilakukan secara tatap muka kemudian dilakukan secara online melalui aplikasi di new media (internet).

Asumsi kedua dalam teori ini adalah media mempengaruhi persepsi kita dan mengorganisasikan pengalaman-pengalaman kita. Dari hasil penelitian ini, ditemukan fenomena kajian online yang dilakukan oleh ustadz-ustadz melalui media radio streaming maupun siaran di televisi. Bila menggunakan media internet streaming, kebanyakan kaum ibu-ibu masih memikirkan paket data yang akan tersedot banyak dibandingkan bila mereka hadir langsung menyimak pengajian secara tatap muka. Meski begitu, media juga berhasil mengubah persepsi bahwa, ternyata kita bisa saja mengikuti kajian secara non tatap muka tanpa berbayar melalui media elektronik seperti televisi dan radio.

Asumsi ketiga dari teori ekologi media adalah media mempersatukan seluruh dunia. McLuhan mengungkapkan istilah komunitas global (global village) untuk menjelaskan bagaimana media mempersatukan dunia dalam ranah politik, ekonomi, sosial, dan sistem kebudayaan.Dari fenomena pandemi COVID-19, berbagai macam media elektronik dan new media berupa internet dan aplikasi turunannya berhasil mempersatukan masyarakat melalui berbagai macam perberitaan terbaru yang dengan cepat disiarkan. Masyarakat dari berbagai daerah bahkan belahan dunia juga dapat mengikuti kajian online atau kebaktian secara online meskipun sebelumnya belum pernah bertemu dan berkenalan secara tatap muka. Jika di era primitive, pertemuan harus dilakukan secara tatap muka agar berkenalan, maka jarak dan ruang sekarang bukanlah hambatan untuk menambah teman atau komunitas keagamaan.

Ekologi media tidak terlepas dari sejarah perkembangan media. Di era primitif, masyarakat diharuskan bertatap muka dan saling mendengarkan. Masyarakat primitif atau maysrakat oral memiliki stabilisasi yang lebih tinggi dibandingkan peradaban manusia lainnya karena untuk berkomunikasi mereka harus menghadirkan seluruh indera mereka untuk berbicara dan mendengar dalam memahami suatu pesan. Era selanjutnya yakni, era abaca tulis (melek huruf), masyarakat barat ketika itu telah mempelajari cara untuk memahami efek dari huruf fonetis ketika mereka membentuk pola tertentu kebudayaannya. Kemudian, era media cetak, ini adalah sumbangan paling besar dari tipografi terhadap manusia adalah kemampuan untuk menyuarakan pendapat tanpa harus menggunakan kekerasan fisik. Selanjutnya, era elektronik yakni ketika computer telah ditemukan yang merupakan perpanjangan sistem syaraf manusia, dan yang saat ini kita nikmati adalah era new media dimana semua aspek kehidupan terintegrasi dengan media yang ditandai dengan kemudahan pencarian informasi melalui jaringan internetdan berkembang pesatnya teknologi elektronik.

Dari fenomena beribadah dari rumah atau worship from home kita melihat masyarakat saat ini sudah jauh lebih pandai dalam mengatasi berbagai masalah yang ada. Seperti halnya adanya teknologi yang semakin cangih seseorang akan berusaha untuk mencari cara bagaimana supaya komunikasi itu tetap terjalin dengan baik tanpa harus bertatap muka, 
kegiatan belajar, bekerja bahkan pelaksanaan ibadah bisa tetap dilakukan. Caranya adalah dengan memanfaatkan media teknologi yang ia miliki sebagai penyambung komunikasi antar individu maupun kelompok.

\section{Kesimpulan}

Ekologi bermedia masyarakat selalu berkembang seiring berkembangnya media dan teknologi informasi. Perkembangan ekologi bermedia ini juga dipengaruhi faktor kebutuhan masyarakat. Media memiliki peranan yang sangat penting bagi manusia, khusunya saat terjadi kasus penyebaran COVID-19 yang saat ini lagi banyak diperbincangkan diseluruh lapisan masyarakat. Komunikasi tatap muka tida bisa dilakukan. Karena semua aktivitas kegiatan yang berada diluar, baik itu dalam hal pendidikan, pekerjaan, maupun ibadah semuanya ditiadakan. Pemerintah menyuruh semua lapisan masyarakat untuk berada di dalam rumah, pendidikan, pekerjaan dan juga ibadah bisa dilakukan dirumah. Pemerintah mengupayakan bagaimana caranya masyarakat ini tetap produktif sehingga membuat cara bagaimana semua kegiatan yang awalnya diluar itu bisa dilakukan di dalam rumah. Namun medianya yang berbeda karena tidak mungkin lagi dilakukan dengan tatap muka, Maka saatnyalah media baru berperan dalam membantu pemerintah dalam mengatasi masalah ini salah satu contoh upaya pemerintah adalah dalam hal pendidikan, seperti tatap muka atau diskusi perkuliahan maupun pekerjaan bisa dilakukan menggunakan aplikasi zoom, google classrom, google meet, Edmodo, dan lain sebagainya, sedangkan kegiatan keagamaan bisa dilakukan dengan melalui live streaming yang bisa diakses oleh siapapun, karena di dalam streaming tersebut berisi kajian-kajian agama oleh ustadz-ustadz

\section{Daftar Pustaka}

Hamidati, Anis. Komunikasi 2.0 Teoritisasi dan Implikasi Yogyakarta: Mata Padi Pressindo, 2011

McQuail, Denis. Teori Komunikasi Massa suatu pengantar, diterjemahkan oleh Agus Dharma dan Aminuddin Ram, Jakarta: Penerbit Erlangga, 1987

Kadiman, Kusmayanto. Tanpa Gaptek danGupsos Menuju Generasi Indonesia Bisa, Jakarta: PTGramedia Pustaka Utama, 2014

Kuswarno, Engkus. Fenomenologi: Metode Penelitian Komunikasi: Konsepsi, Pedoman, dan Contoh Penelitian. Bandung:Widya Padjajaran, 2009

Harahap, Muchyidin Agung. KapitalismeMedia: Ekonomi Politik Berita dan DiskursusTelevisi Yogyakarta: Pustaka Aura, 2013

Sugihartati, Rahma. Perkembangan Masyarakat Informasi dan Teori Sosial Kontemporer, Jakarta: Kencana, 2014

West, Richard dan Lynn H. Turner, Pengantar Teori Komunikasi: Analisis dan Aplikasi. Jakarta: Salemba Humanika, 2018

Soekanto, Soerjono. Sosiologi SuatuPengantar Jakarta: CV Rajawali, 1987

Jurnal Kopis: Kajian Penelitian dan Pemikiran Komunikasi Penyiaran Islam

Volume 03, Issue 1, Agustus 2020 
Iriantara, Yosal Media Relations Konsep,Pendekatan, dan Praktik. Simbiosa Rekatama Media, 2005. 